METALLURGY AND FOUNDRY ENGINEERING - Vol. 35, 2009, No. 1

\author{
Barbara Hutera*
}

\title{
MECHANICAL PROPERTIES OF MODIFIED BINDERS VS. SAND STRENGTH
}

\section{INTRODUCTION}

The physico-chemical processes taking place in a sand-binder system determine the formation in foundry sand mixtures of sand-binder bonds of a specific geometry.

When the liquid binder is added to a foundry sand, the bridges of bonds are formed. Their geometry depends on the binder viscosity and wetting dynamics [1-5]. Examined carefully, the results of the basic research carried out on a quartz sand - binder system show us that the sand acquires its high strength due to the presence of the, so called, non-enveloped bonds $[6,7]$. The said bonds are formed when the physico-chemical parameters of binder are characterised by low viscosity and high wetting dynamics, thus enabling the said binder to quickly spread and reach the respective contact points $[8,9]$. Low viscosity and high wetting dynamics can be achieved either by mixing the binder with proper diluents or by increasing the temperature of the whole system.

The aim of this study was to prove that the geometry of the bridges formed in a sand binder system affects the mechanical properties of the hardened sand.

\section{RESEARCH PART}

\subsection{Materials}

Studies were carried out on a low molecular-weight, diepoxy diane resin characterised by the following parameters:

- molecular mass $\mathrm{M}_{\mathrm{cz}}(300-600 \mathrm{~g} / \mathrm{mole})$,

- epoxy number LE (0.35-0.58),

- density $\mathrm{d}^{25}=1170 \mathrm{~kg} / \mathrm{m}^{3}$,

- viscosity $\eta^{20}=67.61 \mathrm{~Pa} \cdot \mathrm{s}$.

* D.Sc., Ph.D.: Faculty of Foundry Engineering, AGH - University of Science and Technology, Kraków, Poland; e-mail: barbara.hutera@gmail.com 
The diluent for the resin was butyl acetate characterised by the following properties: $\mathrm{M}_{\mathrm{cz}}=116.6 \mathrm{~g} / \mathrm{mole} ; \mathrm{t}_{\mathrm{wrz}}=126.5^{\circ} \mathrm{C} ; \mathrm{d}^{20}=881 \mathrm{~kg} / \mathrm{m}^{3}, \eta^{25}=0.69 \mathrm{mPa} \cdot \mathrm{s} ; \mu^{25}=1.84 \mathrm{D}$.

The hardener for the binder was triethylenetetraamine (Z-1 hardener), added in an amount of $10 \mathrm{wt} . \%$ in respect of the resin content.

\subsection{Methods and equipment}

The properties of the epoxy resin were modified with butyl acetate added in an amount of either 5 or 30 parts by weight.

The binder preparation consisted in mixing the individual constituents in predetermined weight proportions, with later homogenising of the composition and casting of paddle-shaped specimens [7], hardened for 1 hour at $100^{\circ} \mathrm{C}$.

The mechanical properties of the hardened binders were tested using a prototype apparatus for the measurement of adhesion and cohesion forces [11]. Its use enabled recording of the tensile force in function of time. The measurements were taken at $25^{\circ} \mathrm{C}$ applying a constant loading rate of $\mathrm{V}=5 \mathrm{~mm} / \mathrm{min}$.

For modified binders, the results of the tests were verified on sands hardened at $100^{\circ} \mathrm{C}$, performing the tensile test $R_{m}^{u}$ after different times of hardening.

\section{RESULTS AND DISCUSSION}

Figures 1-3 illustrate changes of stress $(\sigma)$ in function of relative displacement $(\varepsilon)$ for pure binder (Fig. 1) and for binder containing modifier added in amounts of 5 and 30 parts by weight (Figs. 2 and 3, respectively).

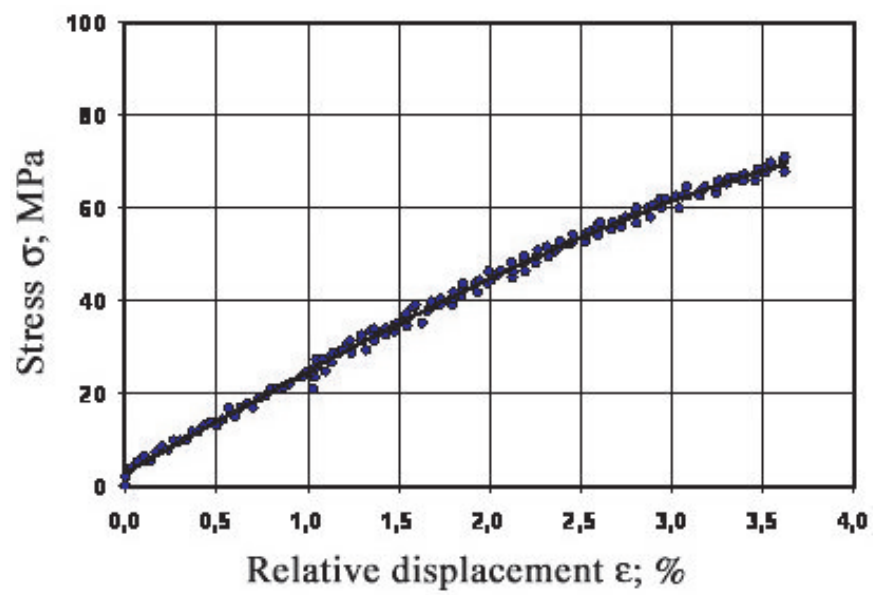

Fig. 1. Stress $\sigma$ changing in function of relative displacement $\varepsilon$ in a specimen of pure epoxy binder; initial specimen thickness $-0.56 \mathrm{~mm}$; hardening conditions: hardening temperature $-100^{\circ} \mathrm{C}$; hardening time $-1 \mathrm{~h}$; test conditions: test temperature $-25^{\circ} \mathrm{C}$, loading rate $-5 \mathrm{~mm} / \mathrm{min}$ 


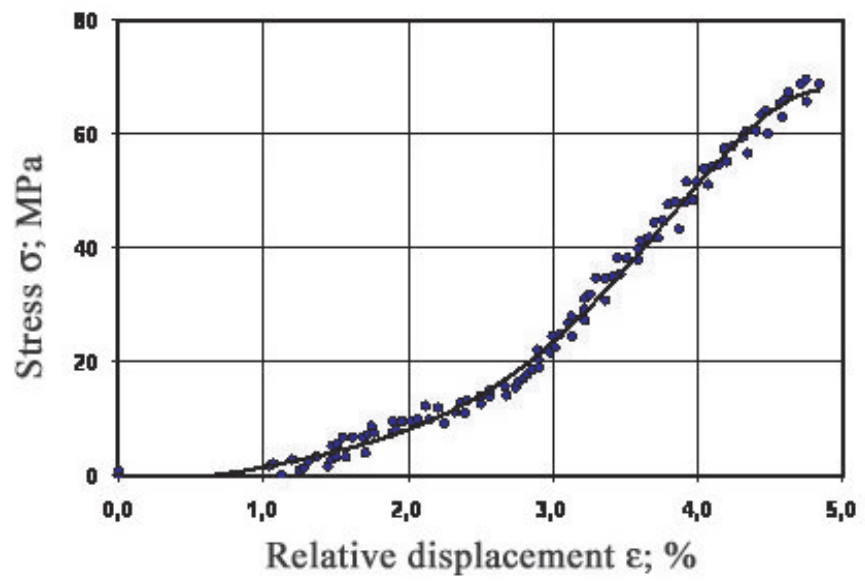

Fig. 2. Stress $\sigma$ changing in function of relative displacement $\varepsilon$ in a specimen of epoxy binder containing 5 parts by weight of butyl acetate: initial specimen thickness $-1.59 \mathrm{~mm}$; hardening conditions: hardening temperature $-100^{\circ} \mathrm{C}$; hardening time $-1 \mathrm{~h}$; test conditions: test temperature $25^{\circ} \mathrm{C}$, loading rate $-5 \mathrm{~mm} / \mathrm{min}$

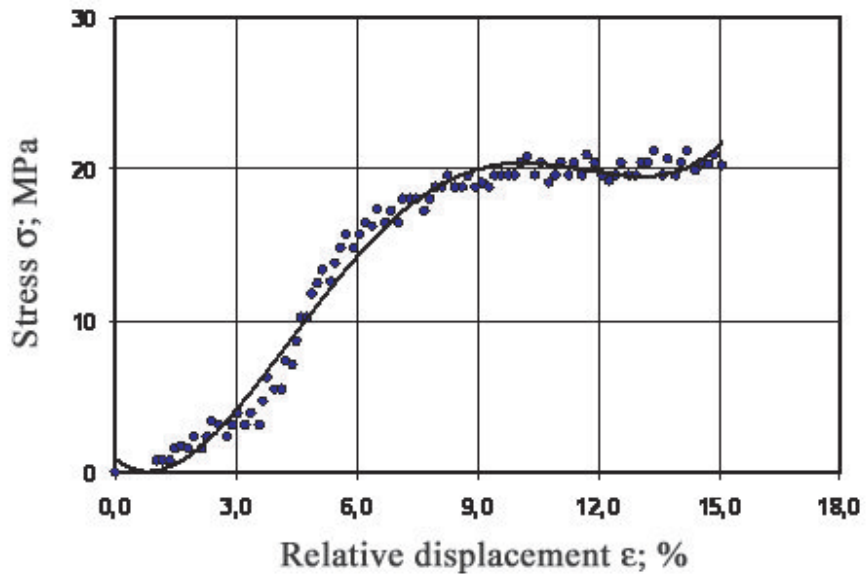

Fig. 3. Stress $\sigma$ changing in function of relative displacement $\varepsilon$ in a specimen of epoxy binder containing 30 parts by weight of butyl acetate: initial specimen thickness $-0.65 \mathrm{~mm}$; hardening conditions: hardening temperature $-100^{\circ} \mathrm{C}$; hardening time $-1 \mathrm{~h}$; test conditions: test temperature $-25^{\circ} \mathrm{C}$, loading rate $-5 \mathrm{~mm} / \mathrm{min}$

As follows from the recorded run of function $\sigma=f(\varepsilon)$, plotted for the binder without an addition of modifier, changes in the strain - displacement system (Fig. 1) are typical of elastic strains.

With small additions of modifier (Fig. 2), the $\sigma=f(\varepsilon)$ curve changes slightly its course; similar changes occur in the value of the breaking stress, which now amounts to about $70 \mathrm{MPa}$. 
Large additions of modifier (Fig. 3) have an important effect on the run of function $\sigma=f(\varepsilon)$ and on the value of the breaking stress. The elongation of specimen typical of plastic strains and a considerable drop in the value of the breaking stress to (about $20 \mathrm{MPa}$ ) are noted.

The differences in the mechanical strength of binders modified with small and large amounts of butyl acetate [7] are confirmed by equations (1-3):

- for pure epoxy resin

$$
\sigma_{K}=72.1 \cdot e^{-0.005 h_{u}} ; R^{2}=0.6597 ; 0.50 \mathrm{~mm}<h_{u}<1.30 \mathrm{~mm}
$$

- for epoxy resin with an addition of 5 parts by weight of butyl acetate

$$
\sigma_{K}=83.7 \cdot e^{-0.222 h_{u}} ; R^{2}=0.41 ; 0.50 \mathrm{~mm}<h_{u}<1.50 \mathrm{~mm}
$$

- for epoxy resin with an addition of 30 parts by weight of butyl acetate

$$
\sigma_{K}=62.9 \cdot e^{-1.72 h_{u}} ; R^{2}=0.81 ; 0.10 \mathrm{~mm}<h_{u}<1.00 \mathrm{~mm}
$$

where: $\sigma_{K}$ is the strength of a specimen of the hardened binder of the height $h_{u}$.

According to the proposed equations [1-3], the cohesive strength of the hardened layer of pure binder of a 0,1 mm thickness amounts to about $72.1 \mathrm{MPa}$, while modification of the binder with small additions of butyl acetate raises this strength to a level of about 81.9 MPa. Large additions of the modifier make this binder behave like a plastic body, thus resulting in an about 25 percent (compared to non-modified resin) drop of cohesive strength to a value of about $53 \mathrm{MPa}$.

Figure 4 illustrates the effect of epoxy binder modification with butyl acetate on the tensile strength $R_{m}^{u}$ of sand held for 3 hours at $100^{\circ} \mathrm{C}$.

Hence it follows that, under the examined conditions of hardening, the tensile strength of the sand with non-modified binder is the lowest. It is changing from about $0.8 \mathrm{MPa}$ to about 1.6 MPa, while the tensile strength $R_{m}^{u}$ of the sand with modified binder is capable of reaching its maximum and constant level (above $2 \mathrm{MPa}$ ) as early as after about $0.5 \mathrm{~h}$ of the hardening process. Sands containing the binder which was modified with large amounts of butyl acetate offered the strength only slightly higher (about 2.4 MPa) than the strength of the sands in which the binder was modified with small additions of ester (about $2.3 \mathrm{MPa}$ ).

The small differences in the achieved strength levels can be explained with different cohesive properties of the hardened binder, approaching the properties of:

- brittle materials - for binder modified with 5 parts by weight of butyl acetate,

- plastic materials - for binder modified with 30 parts by weight of butyl acetate. 


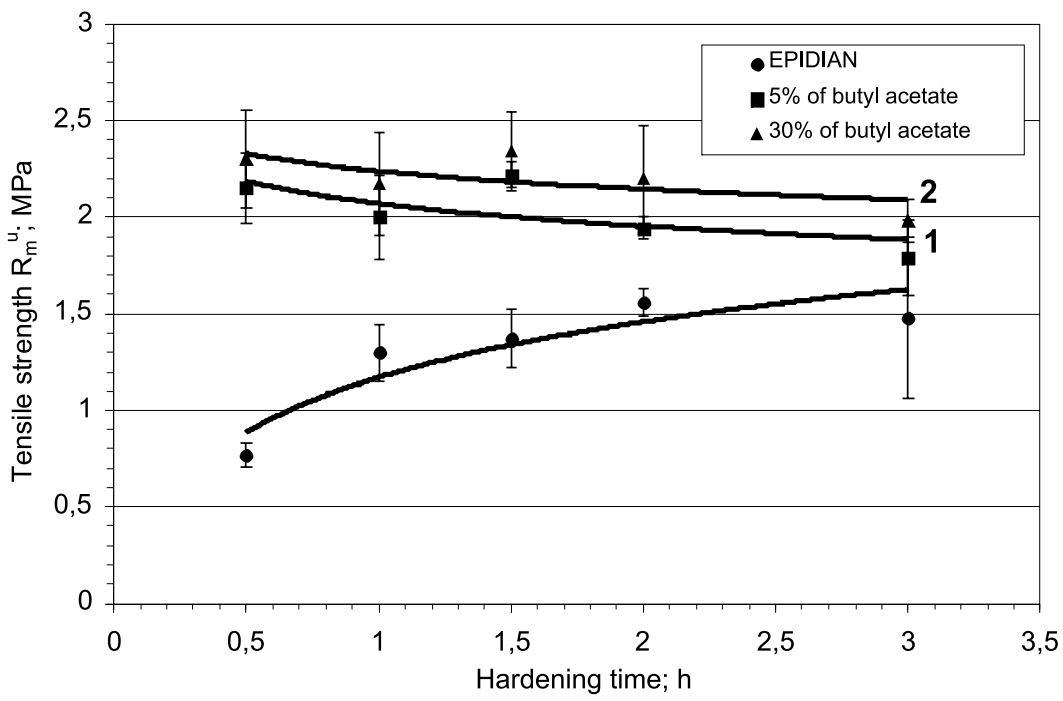

Fig. 4. Effect of hardening time and diluent addition on the sand tensile strength $R_{m}^{u}$; sand composition (in parts by weight): sand from Szczakowa - 100; binder (EPIDIAN 5 resin + butyl acetate) - 0.7; Z-1 hardener - 10wt.\% in respect of resin; mixing conditions: 1) sand + binder - 1.5 min; 2) sand + binder + hardener $-1.5 \mathrm{~min}$; compacting by vibrations; hardening temperature $-100^{\circ} \mathrm{C}$, hardening time $-3 \mathrm{~h}$

\section{SUMMARY}

The physico-chemical properties of the applied binder, such as the viscosity and wetting dynamics, are responsible for the formation in foundry sand of bond bridges of a specific geometry.

The strength of the hardened sand depends not only on the geometry of the bond bridges but also on the mechanical properties of these bridges in as-hardened state - typical of brittle materials when the additions of modifier are small, and of plastic materials when large amounts of the modifier are added.

\section{CONCLUSIONS}

1. The mechanical properties of the hardened sand depend on the physico-chemical parameters of a liquid binder, i.e. on its viscosity and wetting dynamics.

2. The low viscosity of binder resulting in high wetting dynamics favours the formation of bond bridges characterised by an optimum geometry and size.

3. Apart from the viscosity and wetting dynamics, the strength of the hardened sand also depends on the amount of the added modifier; too large addition of the modifier reduces the sand strength by making the binder behave like plastic material. 


\section{REFERENCES}

[1] Hutera B.: The Boundary Cases of Bonds Formation and Modes of their Destruction, Zeszyty Naukowe AGH; ser. Metallurgy and Foundry Engineering, 21 (1995) 3, 225-232

[2] Hutera B.: Znaczenie badań modelowych w prognozowaniu właściwości wytrzymałościowych mas formierskich, Materiały XII Konferencji Sprawozdawczej PAN pt.: „Metalurgia 98”, Krynica (1998), s. $199-204$

[3] Hutera B.: Weryfikacja modelowego układu: 2 kule kwarcowe - mieszanina bentonitu $\mathrm{z}$ wodą w stanie wysuszonym, Materiały Ogólnopolskiej Konferencji z okazji Dnia Odlewnika, Kraków (1993), s. 167-173

[4] Hutera B.: Strength of the Model of Moulding Care Sand System, Zeszyty Naukowe AGH, ser. Metallurgy and Foundry Engineering, 20 (1994) 4, 483-492

[5] Hutera B., Smyksy K.: Analiza modelowych połączeń: osnowa - spoiwo, Materiały Ogólnopolskiej Konferencji z okazji 50-lecia Instytutu Odlewnictwa, s. 29-34, Kraków (1996)

[6] Hutera B.: Wpływ wybranych parametrów fizykochemicznych na wytrzymałość mas formierskich, Archiwum Technologii Maszyn i Automatyzacji, 24 (2004) 1 (specjalny), 115-122

[7] Hutera B.: Znaczenie rozcieńczalnika w spoiwie dla przebiegu zjawisk powierzchniowych w układzie: osnowa piaskowa - materiał wiążący, Wydawnictwo Naukowe AKAPIT, Kraków 2008, ISBN 978-83-6095813-1

[8] Blake T.P., De Coninck J.: The influence of solid - liquid interactions on dynamic wetting, Advances in Colloid and Interface Science, 96 (2002), 21-36

[9] Blake T.P., Shikhmurzaev Y.P.: Dynamic Wetting by Liquids of Different Viscosity, Journal of Colloid and Interface Science, (2002) 253, 196-202

[10] Hutera B., Lewandowski J.L., Drożyński D.: Modyfikacja fizykochemiczna spoiw i osnowy stosowanych w masach formierskich, Projekt badawczy KBN, nr AGH 18.25.170.233, Kraków (2004)

[11] Baliński A., Smyksy K., Lewandowski J.L., Hutera B.: Wybrane aspekty działania aparatu do pomiaru sił adhezji i kohezji materiałów wiążących, Krzepnięcie metali i stopów, 1 (1997) 33, 222-229

Received

November 2009 